Journal of Law \& Social Studies (JLSS)

Volume 3, Issue 1, pp 1-10

www.advancelrf.org

\title{
Distribution of Power between the Centre and Provinces in Pakistan under the Constitution of 1973
}

\author{
Sidra Akram \\ PhD Scholar \\ Department of Political Science and International Relations, \\ Government College University Faisalabad \\ Email: sidraakram200015@gmail.com \\ Dr. Muhammad Azhar \\ Assistant Professor \\ Department of Political Science and International Relations, \\ Government College University Faisalabad, \\ Email: muhammad.azhar@gcuf.edu.pk
}

\begin{abstract}
Centre-Province relationship and the distribution of power between centre and provinces is a complex and multifaceted sort of administrative and political debate for all around the world including Pakistan. Pakistan is based on federation where power has been divided between the central government and their provinces. Pakistan, which is partitioned into four regions, those are performing overwhelming participation in the organization and armed force. The other three units have demonstrated their discontent over the portion of forces between the government and areas and raised their voice for more independence and political shields. This paper will analyze the concept of a federation which considered appropriate for varied political societies to promote coordination and cooperation in the political, social, administrative, and economic sphere. So that it gives the fragile balance to conflicting demands between the centre and their provinces. This paper will discuss the fact, that the constitution of 1973 provides the suitable structural arrangement in Pakistan for union and its unit, but could not alter the power mechanism of the centre. This paper will discuss the prevailing debate of the centre-province relationship and quantum of power-sharing among them.
\end{abstract}

Key Words: Quantum of power, Federation, Constitution of 1973

\section{Introduction}

This paper is based on the conviction of federalism theoretically, which formulated in the Constitution of 1973 in Pakistan. In actual federalism is comparable system of government in which competency and power of governance are belongs to centre and provinces. Federalism considered being appropriate to a cohesive political society in order to create mutual co-operation and harmony in the administrative, political, and socio-economic spheres. However, federalism endows with a fragile balance between the squabbles demands between the centre and provinces.

Perhaps, the history of federalism can be detected by those days when the $1^{\text {st }}$ Islamic state was established in Madina during the days of Holy Prophet (PBUH) where Yahud Ansar and Muhajreen were living simultaneously, respecting the rights of each other and were enjoying the equivalent of rights. "This perhaps could be seen as the loosest form of what later came to be defined as federalism" (Abbasi, 2010). Currently, across the world there are 28 countries that are practicing the federalism including Venezuela, USA, South Africa, Spain, Pakistan, Iraq, India, Germany, Ethopia, Canada, Brazil, Austria and Australia (Kundi, 2002). 
Federalism is adopted between the centre and its federating units to administer and organize their relationship. It is such a tool which provides the spirit of sovereignty and autonomy to the central provinces without affecting the state unity. According to Dicey "a political contrivance intended to reconcile national unity with the maintenance of state rights". (Baxter, 1974). However, these arrangements of power distribution between centre and provinces are reconciled through a constitution. The origin of the federation as far as is concerned with the product of centrifugal and centripetal tendencies. There are economic interests and common dangerous due to which federating units shifted towards federalism. That's the way which leads the concept of federalism in Australia, Switzerland and USA. Moreover, states geopolitical enormity goes ahead on the way to federation and decentralization.

Initially, Pakistan was consisted of Bengal, Baluchistan, Sindh, and Punjab. However, there have been conflicts and controversies in the federal structure of Pakistan since independence. There have been long-standing demands for change, especially "changes to the vertical and horizontal division of resources and demands for a reorganization of provinces along ethno-linguistic lines" (Nazir, 2008). The distribution of power between centre and provinces in Pakistan suffers from several tensions. The numbers of provinces, inequitable and vertical distribution of power and resources between centre and provinces have exacerbated conflicts and tensions, some of them have took a aggressive turn and assumed an ethno-linguistic nature.

The constitution has been amended several times since 1973. However, to roll back these amendments a "Special Parliamentary Commission on Constitutional Reforms" has been amended by the President Asif Ali Zardari. SPCCR has played a herculean role to renewal the parliamentary supremacy with the consensus of stakeholders and all political actors in the constitution of Pakistan. The seasoned Pakistani observers were surprised because level of agreement was unprecedented between provinces and rival political parties partially. The changes proposed by the SPCCR led various changes for power distribution in centre and provinces (Adeney, 2012).

The discussion of federalism has occupied an imperative place since the emergence of Pakistan in all the constitutional debates. In actual the demand of federalism emerged as a device to safeguard to the provinces which will secure their interests against the central government (Waseem, 2011). This article focused on the centre province relationship in Pakistan as well as attempt to examine the constitutional establishment, issues and adjustment of federalism involved. This research work is analytical as well as descriptive in nature. Data related to this study collected by secondary sources such as books, journal articles, encyclopedias, and governmental official records.

\section{Research Questions}

1) What is the Centre-Province relationship and quantum of power-sharing among them?

2) Whether the constitution of 1973 provides the suitable structural arrangement in Pakistan for union and its unit?

\section{Federalism}

A common prevailing form of government is the federal system of government. It is due to the aspect that for those civilizations which are assorted in character, the federal system of government is more appropriate. In the world, different linguistic, ethnic, and cultural groups are involved by most civilizations. The existence of the specific society might be at a stick, if by worthwhile political system the assortment of these groups is not combined. For the two categories of governments which are state/provincial and federal, two detachable groups of subjects are provided by a federal system of government.

Both state and federal governments can use authority by a third list of subjects usually named as concurrent, however, the right of federal government will succeed in the case of differences terminated the use of authority. Hence, from a solitary federal composition both governments originate their powers (B. H. Shafruddin, 2008). The strength of federalism mechanisms from legitimate foundations, where the strength of federalism materialized as a prosperous mechanism of government and a philosophy of politics for the purpose of attaining unity in enormous number of nation-states societies. However, federalism is considered the most significant way which provides shelter provinces and creates political harmony between the centre and provinces (Dawn, 2019).

\section{Constitutionalism and Federalism in Pakistan}

Pakistan had tasted three Constitutions. Although their details are different but retained according to federalism. Historically, there was considerable imbalance demographically and geographically between the both wings of Pakistan. East and west wing of state was completely different on basis of geography and demography. East wing was naturally larger than west wing and it was favorable condition for elites of East wing to accept bicameral legislature. 
It was clearly assuring their supremacy over West wing (Malik, 2001). But on the other hand, elite class of west wing also know this, that's why on the contrary to this they were in favour of parity between two wings as supremacy of East wing was not acceptable for the west elite class especially for Punjab.

Report of Basic Principle Committee in 1950 and 1952 were rejected on the same ground. Then the formula of Muhammad Ali Bogra was suitable to adopt the parity of the both wings (Shah, 2008). This was led towards the federalism in state. East wing already was a one unit and one unit scheme of 1955 to combine Sindh, Punjab, Baluchistan and NWFP in single unit was again a big issue (Rabbani, 2013).

Federal nature of the Constitution faced another issue that was quantum of sovereignty. NWFP and Sindh from western wing and Eastern wing of Pakistan were demanded self-governmental system in Pakistan (to restrict the centre with economic affairs, foreign affairs and defense) (Prajjwal Sharma, 2019). This was another point where Punjab opposed it. Punjab wanted a string center with effective power. Punjab was in favour of the federalism that was set in provisional constitution of 1947. Language issue was another point of both wings had deadlock. Bengali people wanted Bengali as national language but other people with different languages thought it as vulnerable for their languages (Centre, 2002). To break this deadlock Urdu was a single and more suitable solution but Bengali did not agree to accept as national language.

Lastly consensus was acquired by declaring both Urdu and Bengali as the national languages. The constitution of 1956 was short and in written form. In this constitution it was tried to resolve all issues of concerned classes. In this constitution Pakistan is declared as federal state with two provinces West and East (Pervaiz Iqbal Cheema, 2006). This constitution was promulgated on 23rd March 1956. To resolve the provinces and federal related issues, this constitution sanctioned and granted thirty subjects to center and ninety-four to the East and West provinces. Two councils were also set up, the monetary council and the finance commission, these two councils were responsible to advise the central government on the formation of fiscal and taxes and sanctioning of loan related policies (Muntzra Nazir, 2008).

Unfortunately, constitution of 1956 could not get operational and state faced the martial law. All the powers were now converged in single hand with no constitutional attitude. Ayub Khan was a military bureaucrat and he didn't want to introduce any parliamentary democracy. Ayub Khan only worked to strengthen his one-man rule (Ashraf I., 2016). Ayub Khan's constitution introduced the federal system that was mentioned in constitution. The relation between federal government and the federating units is explicitly narrated in the preamble (Tasneem, 2013). This constitution was implemented by the order of the president of Ayub Khan and this declared Pakistan as central government system. In this constitution presidential government system experienced first time and president was the head of both the state and government. The center of all powers was the president (Zulfikar Khalid Maluka, 2008). The members of parliament were answerable in front of president. Same pattern was followed in the provinces where governor were present to speak on the behalf of the President. "The essence of federalism and its utility was rather crushed in a varied cultural, multilingual and demographically imbalanced state with politically noncompromising leadership" (Bossert, 2018).

\section{Major Issues and Adjustment}

According to Dicey "Equal distribution of powers between the centre and unit is essential for federalism." In contemporary world's political system federalism is the most popular form of government, despite of the fact that is does not provide equal distribution between centre and provinces. In most of the cases, centre exercise more powers and units performed under central governments. Similarly, after the inception of Pakistan, the central government maintains a dominant role over the right of the units. It is a clear fact that the dismissal of Khan Sahib Ministry in North West frontier province NWFP (now KPK) in August 22, 1947, M.A. Kharho on April 20, 1948 in Sindh Mamdoth's in Punjab on January 25, 1949, and Fazl-ul-Haq's in 1954 in East Pakistan showed the centre dominant position over the units.

The first and foremost important factor was the long military rule which created hurdles for a democratic setup. The first constituent assembly strengthened the powers and role of central government when constitutional assembly formulated the 1956 constitution, it was rejected, and constitutional government was overthrown by a military coup in October 8, 1958. It was a severe setback to the future democratic system of Pakistan. Furthermore, Ayub regime (1958-1969) and the 1966 constitution consolidated the role of army and bureaucracy.

The 1973 constitution was presented on 14 August 1973, but political instability and chaos still prevailed. To add more to this the 1977 Zia military coup and abrogation of the 1973 constitution further boosted the central government 
powers. The units were severely deprived from the powers when 8th amendment was passed. The amendment provided presidential rights to president to dissolve national assemblies and elected governments. This right was exercised by the president in 1988, 1990, 1993 and 1996 under section 58 (2b). However, the 13th amendment in the constitution rights under article $58(2 \mathrm{~b})$ to dissolve NA and elected government.

The second factor was the absence of constitutional setup during the initial years of the newly born Pakistan the phase paved the way towards strong central government which distorted the basic notion of federalism the constitution history of Pakistan showed that the centre always enjoy more powers as compare to unit's powers. In 1956 constitution the list of legislative powers was given to the centre (Naseer, 2007). However centre had exclusive authority to exercise and make laws related to the distribution between units and centre.

To illustrate this more in 1962 and 1973 constitution this disparity was unbroken. The diverse Pakistan society required a federal system, where provinces exercise legislative, financial and administrative powers the parity formula proved disastrous in ethnically heterogeneous and socio-culturally complex society of Pakistan in 1956 and 1963 the formula pushed the country towards dissatisfaction and disharmony between the two wings. To add more, it created inequality within the provinces of the West Pakistan where people claimed that Punjab had a big share in army and bureaucracy (Farzana Arshad, 2019).

Another bone of contention was the financial arrangement between centre and units from the Riesman award 1951 to the NFC award, the provinces shown reservation because the central government dominated the financial matters. This dominated position of the centre created dissatisfaction in NWFP (now KPK), Sindh and Baluchistan. Cooperation between centre and units is an important feature of the federalism. It is said that effective federalism is based on equal distribution of power. In a multi-cultural and multi-ethnic society like Pakistan, distribution must be based on people's desires and needs. The unequal distributions of powers lead towards provincialism, lack of national unity, multi-party system and so on. In such cases nationist and ethnic slogans arise which create disunity in the country (Nazir M. , 2018).

\section{Centre Province Relations 1973}

Pakistan is a Federal country in nature and comprised of four centrally administrated areas and tribal areas. Thus, the constitution of 1956 and 1962 were also federal but the division of powers under them led to the dissatisfaction with the provinces. However, in the constitution of 1973, provinces were given the internal sovereignty and the element of the separation of power brings satisfaction between the centre and provinces. The constitution of 1973 became the representative's constitution of the whole nation. The longstanding demand for provincial sovereignty was met in the constitution of 1973. By the $18^{\text {th }}$ amendment more provincial autonomy was also given to the provinces (Bukhari, 2013).

Existing constitution contains two lists of legislative subjects - federal and concurrent. Central government is exclusively authorized to make laws regarding federal list while both the federation and provinces can legislate over concurrent subjects. However, in case of any conflict between the federation and provinces, will of federation prevails. Provinces have residuary powers, but the extensive listing of legislative subjects hardly leaves any room for provincial law-making. Similarly, federal administrative system is highly centralized and controlled through the Pakistan Central Superior Services. State of emergency, lack of law and order in provinces or any other unusual occasion gives more powers to central government which then can fully control provincial administration.

Provinces are bound to exercise power in compliance with federal parliament's rules and regulations. Likewise, provincial governor represents federal spirit in provincial administration. $17^{\text {th }}$ Amendment has empowered provincial governor to dissolve provincial assembly (subject to adjudication of High Court). Also, nature of center-provinces coordination mechanism favors federation. Composition of the Council of Common Interests (CCI) is a case in point. It has eight members, four chief ministers and an equal number of central representatives including Prime Minister as the Chairman of CCI.

This constitutional body is responsible to refute any issues related to resources distribution etc. between central and provincial governments. Keeping in mind the political turmoil and separation of the East Pakistan, 1973 constitution was a remarkable achievement. It introduced parliamentary system of government with a bicameral legislature. Prime Minister got the highest administrative office with president merely a state representative. However, there are shortcomings as this constitution does not provide any mechanism to make federal government answerable in case of any unlawful act (Ali, 2016). 
$13^{\text {th }}$ Constitutional amendment revived the original federal spirit of 1973 constitution reducing the immense executive powers of the President. Nawaz Sharif government introduced it which restored the position of Prime Minister as the de jure and de facto chief executive. On October 1999, the then sitting Army chief General Musharraf ousted the Nawaz Sharif government and suspended the constitution. Later, in 2002, he issued a Legal Framework Order (LFO) to provide legal cover to all of Musharraf's 11 orders which he issued as a martial law administrator. Also, it revived the $8^{\text {th }}$ amendment. President got authority to appoint the heads of major civil and military institutions along with the notorious provision 58(2) by authority to dissolve national and provincial legislatures. LFO barred a person to become Prime Minister more than twice (Hamid, 2010). Thus, these measures again hampered the federal spirit of Pakistan constitution. There are some provisions which are made for the distribution of power by the existing constitution. These are following: 


\begin{tabular}{|c|c|c|}
\hline $\begin{array}{c}\mathrm{Sr} \\
\#\end{array}$ & $\begin{array}{l}\text { Certain } \\
\text { Provisions }\end{array}$ & $\begin{array}{c}\text { Constitutional Provisions of } 1973 \text { Powers distribution between Centre } \\
\text { and Provinces }\end{array}$ \\
\hline 1 & $\begin{array}{c}\text { Article } \\
141\end{array}$ & $\begin{array}{l}\text { Parliament may make laws (including laws having extra-territorial } \\
\text { operation) for the whole or any part of Pakistan, and a Provincial } \\
\text { Assembly may make laws for the Province or any part thereof. }\end{array}$ \\
\hline \multirow[t]{4}{*}{2} & \multirow[t]{4}{*}{$\begin{array}{c}\text { Article } \\
142\end{array}$} & $\begin{array}{l}\text { Parliament shall have exclusive power to make laws with respect to any } \\
\text { matter in the Federal Legislative List; }\end{array}$ \\
\hline & & $\begin{array}{l}\text { Parliament, and a Provincial Assembly also, shall have power to make } \\
\text { laws with respect to any matter in the Concurrent Legislative List }\end{array}$ \\
\hline & & $\begin{array}{l}\text { A Provincial Assembly shall, and Parliament shall not, have power to } \\
\text { make laws with respect to any matter not enumerated in either the Federal } \\
\text { Legislative List or the Concurrent Legislative List; and }\end{array}$ \\
\hline & & $\begin{array}{l}\text { Parliament shall have exclusive power to make laws with respect to } \\
\text { matters not enumerated in either of the Lists for such areas in the } \\
\text { Federation as are not included in any Province. }\end{array}$ \\
\hline 3 & $\begin{array}{c}\text { Article } \\
144\end{array}$ & $\begin{array}{l}\text { If two or more Provincial Assemblies pass resolutions to the effect that } \\
\text { Parliament may by law regulate any matter not enumerated in either List } \\
\text { in the Fourth Schedule, it shall be lawful for Parliament to pass an Act for } \\
\text { regulating that matter accordingly, but any act so passed may, as respects } \\
\text { any Province to which it applies, be amended or repealed by Act of the } \\
\text { Assembly of that Province. }\end{array}$ \\
\hline \multirow[t]{2}{*}{4} & \multirow[t]{2}{*}{$\begin{array}{c}\text { Article } \\
145\end{array}$} & $\begin{array}{l}\text { The President may direct the Governor of any Province to discharge as } \\
\text { his Agent, either generally or in any particular matter, such functions } \\
\text { relating to such areas in the Federation which are not included in any } \\
\text { Province as may be specified in the direction }\end{array}$ \\
\hline & & $\begin{array}{l}\text { The provisions of Article } 105 \text { shall not apply to the discharge by the } \\
\text { Governor of his functions under clause (1) }\end{array}$ \\
\hline \multirow[t]{3}{*}{5} & \multirow[t]{3}{*}{$\begin{array}{l}\text { Article } \\
146\end{array}$} & $\begin{array}{l}\text { Notwithstanding anything contained in the Constitution, the Federal } \\
\text { Government may, with the consent of the Government of a Province, } \\
\text { entrust either conditionally or unconditionally to that Government, or to } \\
\text { its officers, functions in relation to any matter to which the executive } \\
\text { authority of the Federation extends. }\end{array}$ \\
\hline & & $\begin{array}{l}\text { An Act of Parliament may, notwithstanding that it relates to a matter with } \\
\text { respect to which a Provincial Assembly has no power to make laws, } \\
\text { confer powers and imposes duties upon a province or officers and } \\
\text { authorities thereof. }\end{array}$ \\
\hline & & $\begin{array}{l}\text { Where by virtue of this Article powers and duties have been conferred or } \\
\text { imposed upon a Province or officers or authorities thereof, there shall be } \\
\text { paid by the Federation to the Province such sum as may be agreed or, in } \\
\text { default of agreement, as may be determined by an arbitrator appointed by } \\
\text { the Chief Justice of Pakistan, in respect of any extra costs of } \\
\text { administration incurred by the Province in connection with the exercise of } \\
\text { those powers or the discharge of those duties. }\end{array}$ \\
\hline \multirow[t]{3}{*}{6} & \multirow[t]{3}{*}{$\begin{array}{c}\text { Article } \\
147\end{array}$} & $\begin{array}{l}\text { The executive authority of every Province shall be so exercised as to } \\
\text { secure compliance with Federal laws which apply in that Province }\end{array}$ \\
\hline & & $\begin{array}{l}\text { Without prejudice to any other provision of this Chapter, in the exercise } \\
\text { of the executive authority of the Federation in any Province regard shall } \\
\text { be had to the interests of that Province. }\end{array}$ \\
\hline & & It shall be the duty of the Federation to protect every Province against \\
\hline
\end{tabular}




\begin{tabular}{|c|c|c|}
\hline & & $\begin{array}{l}\text { external aggression and internal disturbances and to ensure that the } \\
\text { Government of every Province is carried on in accordance with the } \\
\text { provisions of the Constitution. }\end{array}$ \\
\hline \multirow[t]{3}{*}{7} & \multirow[t]{3}{*}{$\begin{array}{c}\text { Article } \\
149\end{array}$} & $\begin{array}{l}\text { The executive authority of every Province shall be so exercised as not to } \\
\text { impede or prejudice the exercise of the executive authority of the } \\
\text { Federation }\end{array}$ \\
\hline & & $\begin{array}{l}\text { The executive authority of the Federation shall also extend to the giving } \\
\text { of directions to a Province as to the carrying into execution therein of any } \\
\text { Federal law which relates to a matter specified in the Concurrent } \\
\text { Legislative List and authorizes the giving of such directions }\end{array}$ \\
\hline & & $\begin{array}{l}\text { The executive authority of the Federation shall also extend to the giving } \\
\text { of directions to a Province as to the construction an d maintenance of } \\
\text { means of communication declared in the direction to be of national or } \\
\text { strategic importance }\end{array}$ \\
\hline \multirow[t]{2}{*}{8} & \multirow[t]{2}{*}{$\begin{array}{c}\text { Article } \\
151\end{array}$} & $\begin{array}{l}\text { Parliament may by law impose such restrictions on the freedom of trade, } \\
\text { commerce or intercourse between one Province and another or within any } \\
\text { part of Pakistan as may be required in the public interest. }\end{array}$ \\
\hline & & $\begin{array}{l}\text { A Provincial Assembly or a Provincial Government shall not have power } \\
\text { to-make any law, or take any executive action, prohibiting or restricting } \\
\text { the entry into, or the export from, the Province of goods of any class or } \\
\text { description, or impose a tax }\end{array}$ \\
\hline \multirow[t]{2}{*}{9} & \multirow[t]{2}{*}{$\begin{array}{c}\text { Article } \\
152(2) A\end{array}$} & $\begin{array}{l}\text { There shall be a Council of Common Interests The members of the } \\
\text { Council shall be-the Chief Ministers of the Provinces, and an equal } \\
\text { number of members from the Federal Government to be nominated by the } \\
\text { Prime Minister from time to time }\end{array}$ \\
\hline & & $\begin{array}{l}\text { If the Federal Government or a Provincial Government is dissatisfied } \\
\text { with a decision of the council, it may refer the matter to Majlis-e-Shoora } \\
\text { in a joint sitting whose decision in this behalf shall be final. }\end{array}$ \\
\hline \multirow[t]{2}{*}{10} & \multirow[t]{2}{*}{$\begin{array}{l}\text { Article } \\
156\end{array}$} & $\begin{array}{l}\text { The President shall constitute a National Economic Council consisting of } \\
\text { the Prime Minister, who shall be its Chairman President shall nominate } \\
\text { one member from each Province on the recommendation of the } \\
\text { Government of that Province }\end{array}$ \\
\hline & & $\begin{array}{l}\text { The National Economic Council shall review the overall economic } \\
\text { condition of the country and shall, for advising the Federal Government } \\
\text { and the Provincial Governments, formulate plans in respect of financial, } \\
\text { commercial, social and economic policies }\end{array}$ \\
\hline \multirow[t]{2}{*}{11} & \multirow[t]{2}{*}{$\begin{array}{l}\text { Article } \\
157\end{array}$} & $\begin{array}{l}\text { The Federal Government may in any Province construct or cause to be } \\
\text { constructed hydro-electric or thermal power installations or grid stations } \\
\text { for the generation of electricity and lay or cause to be laid inter-provincial } \\
\text { transmission lines }\end{array}$ \\
\hline & & $\begin{array}{l}\text { The Government of a Province may to the extent electricity is supplied to } \\
\text { that Province from the national grid, require supply to be made in bulk for } \\
\text { transmission and distribution within the Province: levy tax on } \\
\text { consumption of electricity within the Province; construct power houses } \\
\text { and grid stations and lay transmission lines for use within the Province; } \\
\text { and determine the tariff for distribution of electricity within the Province }\end{array}$ \\
\hline 12 & $\begin{array}{l}\text { Article } \\
159\end{array}$ & $\begin{array}{l}\text { The Federal Government shall not un reasonably refuse to entrust to a } \\
\text { Provincial Government such functions with respect to broadcasting and } \\
\text { telecasting }\end{array}$ \\
\hline
\end{tabular}




\section{Eighteenth Amendment}

The $8^{\text {th }}$ and the $17^{\text {th }}$ amendment modified federal and parliamentary features in the constitution, as it's discussed earlier. Presidents discretionary powers provides quasi-federal outlook to the constitution (Muhammad Imran Ashraf, 2016). According to parliamentary democracy, President performed as the representative of the federation as well as a titular head of the state while as a people representative Prime Minister performs the actual duties. But the implementation of $8^{\text {th }}$ and $17^{\text {th }}$ amendment situation was opposite. However, the situation was changed again due to $18^{\text {th }}$ amendment (Zafarullah Khan, 2013). The true spirit of the constitution was restored by the $18^{\text {th }}$ amendment. Supremacy or sovereignty of Parliament was restored, and provincial autonomy was also provided by this amendment as imagined in the 1973 constitution.

The $18^{\text {th }}$ amendment enhanced the powers of provincial assemblies regarding legislation by deleting the $4^{\text {th }}$ schedule from the constitution and guaranteed more powers and control to the provincial governments above legislation and budgets (Nuri, 2014). This amendment also gives the consultative role to the provinces regarding any hydro-electric construction wrote in the particularly relevant provinces. Two new clauses (3A) regarding administration and implementation of the NFC award were added to the constitution in Article 160. Article 161 ensured that the province having oil and gas reserves shall be its beneficiary (Ashraf, 2016).

The 18th amendment has greatly enhanced the political stability within marginalized provinces of Pakistan. Such as, Baluchistan is heavily or profoundly indulged in mainstream politics (Nishtar, 2009). However, it can be said that the provincial assemblies became more strengthened or empowered than ever before in true spirit with reducing the federal powers by the $18^{\text {th }}$ amendment (Abbasi, 2010). Federation controls financial resources of the entire country. Provinces depend upon financial support from federal divisible pool to finance development plans. Main source of provincial income are taxes on agricultural income, luxury items and land revenue (Iftikhar Ahmed, 2007). While federation is authorized to tax all other financial sources including natural resources, national exports, customs etc. However, constitution provides for the formation of a finance commission for justifiable distribution of revenues between center and provinces. Here again, center dominates as the President is the sole authority to form the said commission.

\section{Conclusion}

Federalism and provincial autonomy were the founding principles of the Lahore Resolution of 1940. Unfortunately, after Pakistan came into being, this spirit was denied constantly by federal authorities. Historical facts reveal that behind the saga of the separation of the East Pakistan, power sharing between center and provinces was a major discord. Center did every effort to maintain power dominance since the constitution of Pakistan. Administrative, legislative and fiscal decentralization are causing a sense of alienation among the federating units. Rise of radical movements in some parts of the country, can be seen as a result of biased policies of the federation. Immediate and sincere efforts are required to deal with the above-mentioned aspects of federation of Pakistan. Best way is to follow the constitution, restore the supremacy of parliament and give provinces their due share as mentioned in the 1973 constitution. There are following recommendations to promote harmony between centre and provinces.
i. Just distribution of financial resources
ii. Making constitutional bodies such as CCI and NFC etc. strong to deal center-provinces matters
iii. No interference of central government into provincial affairs
iv. Prioritizing cooperation for the overall national development as a common agenda

\section{References}

Abbasi, Z. F. (2010). Federalism, Provincial Autonomy,and Conflicts. Islamabad-Pakistan: Centre for Peace and Development Initiatives (CPDI). ISBN: 978-969-9622-00-7

Adeney, K. (2012). A Step Towards Inclusive Federalismin Pakistan? The Politics of the 18th Amendment. Publius The Journal of Federalism, 42(4), 539-565. doi:10.2307/41682902

Ali, S. M. (2016). Devolution of Power in Pakistan. Washinghton: United States Institute of Peace. Retrieved from https://www.usip.org/sites/default/files/2018-03/sr_422_mohammad_ali_final.pdf 
Ashraf, I. (2016, September 1st). federalism and Provincial Autonomy. International Journal of Humanities and Social Science, 4(5), 23-35.

Ashraf, M. I. (2016). Federalism and Provincial Autonomy:Political and Economic Dimensions under theConstitution of Pakistan 1973. Department ofPolitics andInternational Relations. Islamabad: International Islamic University Islamabad.

B. H. Shafruddin, I. A. (2008). Between Centre and State: Federalism in Perspective (1st ed.). Malaysia: Institute of Strategic and International Studies Malaysia.

Baxter, C. (1974, December). Constitution Making: The Development of Federalism in Pakistan. Asian Survey, 14(12), 1074-1085. doi:10.2307/2643201

Bossert, T. J. (2018). Distribution of Power between the Federation and the Provinces. In G. P. Marchildon, Federalism and Decentralization in Health Care: A Decision Space Approach (pp. 1-275). Toronto: University of Toronto Press.

Bukhari, S. M. (2013). A Comparative Study of Federalism in Pakistan after 18th Amendment. Pakistan Journal of Social Sciences (PJSS), 33(1), 109-120.

Centre, P. S. (2002). Pakistan Perspectives (Vol. 7). Karachi: Pakistan Study Centre, University of Karachi.

Dawn. (2019). Centre-Province Ties. Islamabad: Dawn Newspaper. Retrieved from https://www.dawn.com/news/1462149

Farzana Arshad, F. H. (2019). The National Finance Commission Award and Centre-Province Relationship: A Study of Pakistani Federal Structure. Journal of the Research Society of Pakistan, 56(1), 228-235.

Hamid, M. S. (2010). Impact of the 18th Constitutional Amendment on Federation-Provinces Relations. Islamabad: Pakistan Institute for Legislative Development and Transperancy. Retrieved from https://pildat.org/parliamentary-development1/impact-of-the-18th-constitutional-amendment-on-federationprovinces-relations-2

Iftikhar Ahmed, U. M. (2007). National Finance Commission Awards in Pakistan: A Historical Perspective. Pakistan Institute of Development Economics . Islamabad: PIDE Working Papers.

Kundi, M. A. (2002). Federalism in Pakistan: Problems and Prospects. Asiuan and Africian Studies, 1(1), $27-48$.

Malik, A. (2001). Ideology and Dynamics of Politics in Pakistan (1st ed.). Lahore, Pakistan: Publishers Emporium.

Muhammad Imran Ashraf. (2016). Federalism and Provincial Autonomy:Political and Economic Dimensions under the Constitution of Pakistan 1973. Islamabad: International Islamic University.

Muntzra Nazir. (2008). Federalism in Pakistan: Early Years. Lahore, Pakistan: Pakistan Study Centre, University of the Punjab.

Naseer, S. (2007). Federalism and Constitutional Development in Pakistan. Nepal, Khatmandu: Centre for Nepal and Asian Studies.

Nazir, D. M. (2008, June). The Problems and Issues of Federalism in Pakistan. Pakistan Vision , 9(1), $109-128$. Retrieved from http://www.nazariapak.info/Our-Pakistan/Problems.php

Nazir, M. (2018). The Problems and Issues of Federalism in Pakistan. Pakistan Vision, 9(1), 218-229.

Nishtar, D. S. (2009). The federation and provincial autonomy. Lahore: The News International.

Nuri, M. u. (2014). Eighteenth Amendment Revisted. Islamabad: Islamabad Policy Research Institute.

Pervaiz Iqbal Cheema, R. A. (2006). Problems and Politics of Federalism in Pakistan (The University of Michigan ed.). Islamabad, Pakistan: Islamabad Policy Research Institute, Hanns-Seidel-Stiftung. 
Prajjwal Sharma, Y. S. (2019). IAS Mains Paper 2 Governance Constitution, Polity Social Justice \& International Relations 2020 (1st ed.). New Delhi: Arihant Publications India limited.

Rabbani, M. R. (2013). A Biography of Pakistani Federalism Unity in Diversity. Islamabad, Pakistan: Leo Books Federal government.

Shah, S. M. (2008). Federalism in Pakistan: Theory and Practice. Islamabad, Pakistan: Chair on Quaid-i-Azam \& Freedom Movement, National Institute of Pakistan Studies, Quaid-i-Azam University, 1994.

Tasneem, S. (2013, September). Working Relationship between Central and Provincia Governmnets in Pakistan. International Journal of Humanities and Social Science, 3(17), 23-33.

Waseem, M. (2011, September). Pakistan: A Majority-Constraining Federalism. India Quarterly, 67(3), 213-228.

Zafarullah Khan, A. R. (2013). Features on Federalism. Islamabad: SPFD, UNDP-Pakistan.

Zulfikar Khalid Maluka, Z. K. (2008). The Myth of Constitutionalism in Pakistan (1st ed., Vol. 1). Lahore: Oxford University Press. 